\title{
A Content Analysis of the Portrayal of India in Films Produced in the West
}

\author{
SRIVIDYA RAMASUBRAMANIAN \\ Department of Communication, Texas AGM University, College Station, Texas, USA
}

\begin{abstract}
A content analysis of randomly selected films $(N=24)$ about India produced from 1930-2000 in the US or UK was undertaken to examine the social construction of "Indian-ness." There were significant inter-group differences in depictions of Indian versus non-Indian scenes $(N=1016)$ and Indian versus non-Indian characters $(N=421)$ across several socio-cultural variables such as character role, occupation, poverty, religious practices, and pollution. Overall, India was consistently portrayed as backward, uncivilized, savage, and traditional. These patterns of stereotypical portrayals of India across films are discussed in the context of schema theory, social identity theory, and cultural colonization.
\end{abstract}

KEYWORDS media portrayals, stereotypes, films, content analysis, India

Our understanding about other cultures and nations around the world is often colored by our memory of these places that we have received through mediated visual information (Mitra, 1999). Although numerous inter-related social forces might contribute to our perceptions of others, mass media portrayals undoubtedly play a very important role in influencing people's attitudes towards out-groups, especially when presented in very realistic ways in media such as films.

Films play an important role in shaping ethnic and national identities, especially in the absence of much face-to-face interactions with these groups. They help to create and perpetuate national stereotypes. For example, it would not be surprising if many Americans learn about Africans through Tarzan films, about Arabs from movies such as The Mummy, about China

Address correspondence to Dr. Srividya Ramasubramanian, Department of Communication, 211 Bolton, 4234 TAMU, Texas A\&M University, College Station, TX 77843-4234. E-mail: srivi@tamu.edu 
in films such as The Last Emperor, and about nations such as Russia and North Korea from James Bond pictures. As for India, films such as Gunga Din, Jungle Book, A Passage to India, Indiana Jones: Temple of Doom, Around the World in Eighty Days, Gandhi, Octopussy, and The Man Who Would Be King might have an impact on how moviegoers in the West perceive India.

Over a period of time, through repeated exposure to the same or similar stereotypical depictions across films and across narratives in different media sites, we unintentionally and often unconsciously start accumulating these bits and pieces of information about the social group in such a way that we develop a "schema" or a quick short-cut reference for the social group. Not surprisingly, when asked to recall the attributes of the social group, people might recall scenes, characters, lines, settings, and actors from various films in an attempt to grab whatever little information we can get to make quick judgments in interpersonal situations. Thus, it is crucial to examine what types of portrayals of various marginalized groups are presented within this medium.

In this context, the current content analysis attempts to examine the nature of portrayals about India and its peoples represented in feature films produced in the West. Such an examination not only helps trace the trend that such portrayals have followed with time but also serves as a first step in establishing the chain of events between exposure to media stereotypes and their effects on viewers' attitudes and behaviors in inter-group interactions with members of stigmatized group.

\section{STEREOTYPES OF RACIAL MINORITIES ACROSS VARIOUS MEDIA}

Although one of the first studies that examined the social-psychological effects of media exposure on racial/ethnic attitudes looked at film content (Peterson, Thurstone, Shuttlesworth, \& May, 1933), more recent research on racial stereotypical content has been conducted on various other media sources such as news stories, television programs, music videos, and magazine advertisements (Brown \& Campbell, 1986; Coltrane \& Messineo, 2000; Entman, 1992, 1994a, 1994b; Mastro \& Greenberg, 2000; Mok, 1998; Oliver, 1994; C. R. Taylor \& Lee, 1994; Thomas \& Treiber, 2000). With regard to depictions of racial minorities in American television, for instance, groups such as Native Americans and Asian Americans remain rather invisible (Mastro \& Greenberg, 2000; Mastro \& Stern, 2003). Apart from such gross under-representation of racial minorities, another major concern is that members of these racial groups are often depicted in simplistic, stereotypical ways. To illustrate, blatant stereotypical depictions of African Americans as dangerous, lazy, poor, and clownish (Entman, 1992, 1994a, 1994b; Mastro \& Greenberg, 2000; Oliver, 1994) and of Asian Americans as sly, submissive, 
and as 'model Minorities' (Mok, 1998) continue to dominate media narratives (C. R. Taylor \& Lee, 1994).

Thus, prior research examining North American media suggests that formulaic depictions of racial minorities such as African Americans, Latinos, and Asian Americans continue to persist in contexts such as print and television even in contemporary media channels without much change over time. In trying to contextualize the study of film vis-à-vis these other types of media where racial depictions have been studied, one can make the argument that just as racial stereotypes in print and television media have been known to influence racial attitudes and ethnic identities, film also plays a very important role in attitude formation. Because of its ability to create a realistic presentation of real world experiences by combining both audio and visual modes, cinema has emerged as a powerful medium in shaping the imagination of its viewers through vivid audio-visual aesthetic experiences. Moreover, technological innovations have made films available not just in cinema halls but also on network television, videocassettes, pay-per-view channels, and on the Internet (Oliver \& Kalyanaraman, 2002). Such innovations make repeated viewing of films easily possible for interested audiences, even if the films are classics produced many years ago. In sum, the pervasive influence of film as a medium makes it an important source of information in shaping our perceptions of other cultures, especially because many films are set in foreign locales.

Although most of the above-mentioned content analyses have focused on cultural representations and inter-group relations of racial/ethnic groups within American society, these findings are also help in understanding the hegemonic processes through which the "first world" subjugates "third world" nations through imperialistic narratives. Given that the focus of the current study is on depictions of India in the West, some of the commonly represented themes in such media texts, as well as some factors that influence such depictions, are examined next.

\section{REPRESENTATIONS OF THIRD WORLD IN WESTERN NARRATIVES}

Depictions of India in the West can be examined from the broader framework of representations of so-called third world countries in Western media. As a starting point, it is important to examine how the historical and political contexts of power relations between the first and third World countries influence media content. ${ }^{1}$ Gallagher (1989) noted that it is usually third world countries that have to deal with marginalization problems with respect to information flow. There is a greater flow of information from the first to third world countries but very little representation of the third world in the first world (Mowlana \& Wilson, 1990). This imbalance in information flow, the lack of accurate and diverse sources of information, and the absence of racial 
minorities in the Western media workforce have been cited as some of the possible sources for the problem of misrepresentation of these peoples in the West (Shohat \& Stam, 1994).

Such marginalization is not just evident in the lack of third world-related information in the Western news media but it can also be noted in the absence of characters and plots from third world countries within entertainment media. Westerners are almost always at the center of the story and the third world people, especially women, are given only trivial insignificant roles (Kaplan, 1997). Even when media content occasionally feature third world characters, they are very often portrayed in condescending, negative, and stereotypical ways. For instance, past research on representations of African people in Western films reveal that they are often portrayed as savage cannibals or innocent primitive people (Cameron, 1990; Ukadike, 1990). Whereas the role of the Western characters is complex in these narratives, those of third world Characters are simplistic and almost predictable. The latter are usually present only as embellishments that help define the heroic nature of the Western characters. Moreover, Shohat (1991) pointed out that even when Hollywood films include third world locations in their plots, typically such locations act as the backdrop for the main narrative such that the focus is on exaggerating socio-religious practices in spectacular ways to act as symbols to signify the place. Although one motivation for use of such cultural symbols was to orient the audience to the scene locale, such imagery also served to justify the need to "civilize" third world regions such as India and Africa by European military rulers and Christian missionaries (Ukadike, 1990).

\section{PORTRAYALS OF INDIA IN WESTERN NARRATIVES}

Prior research on portrayals of India reveals similar patterns of subordination and oppression discussed in the larger context of Third World countries in general. The history of stereotypical representations of India largely dates back to colonial rule in India when the narrative accounts and photographic illustrations by missionaries, anthropologists, and government officials focused on depicting Indians as savage and uncivil simple folks (Merchant, 1998; Narayan, 1997). Historically, Europeans portrayed themselves as representing liberty, equality, progress, change, and dynamism in such accounts. In contrast, India was depicted as unhistorical, caught up with traditions - static, inert, or in a process of decline. Indian nationalists did not defy such stereotypical depictions but used them instead as an anchor to justify their fight for freedom from European control. That is, they argued that Western settlers were an interruption to the traditions and values of the glorious ancient Indian past. However, even after more that 50 years of independence of India from European colonizers, post-colonial narratives of India created not just in Europe but also in North America continue to use 
similar themes of White, Caucasian, Western supremacy (Mitra, 1999; Shome, 1996).

On one hand, the depictions that focused on depicting India in condescending ways dealt with "clashes of civilizations" where Western characters "saved" India from ancient religious practices such as voodoo and sorcery, natural disasters such as floods and epidemics, as well as social injustices such as sati and poverty (Mitra, 1999; Shome, 1996). On the other hand, there has also been a tendency for certain films produced in the West to depict India in a dream-like, utopian manner where India is often represented as the land of milk and honey where overindulgences, excesses, and vices are an integral part of the culture. The use of such types of seemingly positive stereotypes has also been referred to as the cultural riches approach that seemed to portray India as a virgin unexplored land waiting to be enjoyed by Westerners without acknowledging any anti-colonial sentiments (Narayan, 1997).

With respect to the types of character roles assigned to Indians, such imperialistic discourses portray the Orient as either child-like or demonic. Specifically, prior research suggests that Indian adult characters take on villainous, anti-Western roles whereas Indian children are presented as innocent and pro-Western (Shohat \& Stam, 1994; Shome, 1996). Such distinctions suggest the presence of an imagined new India that would break out of its traditional past and embrace Westernized progress. According to Mitra (1999), the main motivation for the stereotyping of Indian characters in Western films is to create a distinction between Western and non-Western characters. Therefore, the images of peoples from India focus on skin color, dress, and physical characteristics that serve to create this contrast.

Given that the current content analyses of cinematic portrayals of India is seen as a first step in understanding the ways in which beliefs, feelings, and behaviors toward Indians are shaped, it is important to examine prior research on the relationships between media exposure and attitude formation.

\section{EFFECTS OF MEDIA STEREOTYPES ON VIEWERS' ATTITUDES}

From a social-cognitive perspective, the presence of unidimensional stereotypical media portrayals is a cause for concern because viewers often assimilate such information into longterm memory. Prior research informs us that exposure to stereotypical media content is accumulated into a generalized notion about all members of the group that is being portrayed. Such information is stored as schemas that act as quick short-cut references (heuristics) for the social group (Fiske \& Taylor, 1991; Hansen \& Krygowski, 1994; S. E. Taylor \& Crocker, 1981; Wicks, 1992). In other words, the schematic information itself might greatly influence attention, perception, and memory for 
newly encountered information about the target group. Apart from storing and retrieving such schematic information, it is also possible that vivid, spectacular, concrete, and emotionally charged media exemplars (especially anecdotes and personalized information) are especially likely to be coded more effectively in viewers' minds. Such portrayals, even if they are from fictional entertainment content, are often retrieved subconsciously when viewers make evaluations of the stereotyped population (Busselle \& Shrum, 2003; Gibson \& Zillmann, 2000; Macrae et al., 1998; Zillmann \& Brosius, 2000).

From a media cultivation perspective, continued exposure to such formulaic portrayals across various media outlets is likely to influence viewers' attitudes about out-groups by creating a false notion that portrayals in the media are close to the real world (Fujioka, 1999; Gerbner, 1998; Gerbner, Gross, Morgan, Signorielli, \& Shanahan, 2002; Shapiro \& Lang, 1991). Therefore, media such as television and films that are able to create a realistic presentation using both audio and visual modes seem to be especially likely to create vicarious experiences for viewers, leading to powerful effects on viewer's perceptions of social reality. In particular, research studies have documented the ways in which viewers' racial attitudes are affected by long-term exposure to television programming (Armstrong, Neuendorf, \& Brentar, 1992; Busselle \& Crandall, 2002; Matabane, 1988). Studies on inter-group communication have also shown that such effects are especially more pronounced when there is very little direct contact between groups (Armstrong et al., 1992; Fujioka, 1999). That is, the media will play an influential role in shaping opinions and beliefs about out-groups especially when one has very little chance to interact in meaningful ways with members of such groups. In the context of the films that were produced about India, it is highly possible that most of the audience members did not have much direct contact with people living in India. Therefore, the study of mediated portrayals is even more crucial, given their more powerful role in influencing perceptions of India in the West.

With regard to the functional aspects of stigma and prejudice toward out-groups, social identity theory suggests that members of a group gain self-esteem by identifying themselves strongly with their own group and by contrasting themselves from out-groups (Crocker \& Major, 1989; Fein \& Spencer, 1997; Tajfel \& Turner, 1979). People create emotional and psychological bonds between their personal self-identity and collective group identity such that social reality might become categorized as "us" versus "them". This perspective suggests that people have a need to maintain a favorable self-image and will therefore be much more positively biased toward their in-groups but quite negatively disposed toward out-groups. Related to social identity theory is social comparison theory that suggests that people might make downward social comparisons with those whom they see as less fortunate for self-enhancement (Festinger, 1954; Wills, 1987). In fact, people might often resort to putting down members of out-groups so that their in-group 
would appear to be more superior in comparison. Negative stereotypes and ethnocentrism serve as means of increasing one's positive identity. Therefore, these theoretical perspectives help us understand the motivations that might lead Western film makers to make stark contrasts between the West and the East within their narratives and also present their in-group (West) as superior.

In summary, prior research suggests that narratives about third world countries such as India produced in the West might present stereotypical representations in order to orient audiences to the locale, create distinct social categories amongst in-groups and out-groups, and create a positive social identity for in-groups. Such representations might especially be more influential in shaping attitudes when there are not many opportunities for one-on-one interactions between in-group and out-group members.

The current study contributes to this literature by systematically analyzing portrayals of India and its people in films made in the United States and/or the United Kingdom. In particular, it examines whether the films repeatedly associated India or Indian people with certain characteristics, including environmental conditions, locals, modes of transportation, language, diet, and so forth.

\section{RESEARCH QUESTIONS}

Given that the primary purpose of this project was to examine when, where, and how India and its people are portrayed within films produced in the West, the following research questions were proposed:

RQ1: At the scene level, is there a relationship between the country depicted in a scene (India or outside India), and, the portrayals of climate, pollution, locales, transportation, animals, religious practices, leisure activities, status of women and children, and poverty?

RQ2: At the character level, is there a relationship between ethnicity/nationality of a character (Indian and non-Indian), and the role, gender, occupation, class, place of residence, and language of the characters?

\section{METHOD}

Content analysis was used to examine 1,016 scenes and 421 characters from 24 randomly selected movies

\section{Sample}

The population consisted of feature films produced in the United States and/or United Kingdom that involved India as one of the primary locales and/or have Indian characters in their plots. A database of such films was created using secondary sources of information such as previous literature 
on Indian films, video rental charts in Billboard magazine, extensive film reviews in The Internet Movie Database archives, and filmographies about third world films such as Mitra (1999), and film catalogues such as those compiled by Cyr (1991). From the total population of about 125 films that were identified from these sources, 24 films were selected using simple random sampling procedures. ${ }^{2}$ The appendix lists the films that were selected randomly for this study.

Films released from 1930 to 2000 have been included for analysis. Film scholars have stated that the 1930s was when the West started turning toward other locations in the third world for their film narrative plots (Mitra, 1999) Therefore, it was decided to go as far back as $1930 .{ }^{3}$ Films produced in the United Kingdom were included because of the easy availability of such films to the American viewers, the use of the English language, and the historical influence of Hollywood on the British film industry.

\section{Units of Analysis}

The films were examined at two levels (units of analysis)—scene and character. The scene analysis compared portrayals of India and Western countries. ${ }^{4}$ A scene was defined as a division of the feature film that presented continuous action in one place or a single unit of dialogue taking place in India or/ and within which Indians appear in the narrative.

Overall, there were 1,016 scenes of which 605 were set in India and 411 were set in the West. Dialogue-speaking characters were observed for the entire film before recording their characteristics. In total there were 421 characters of which 200 were identified as Indian and 221 as non-Indian.

\section{Coding Categories}

\section{SCENE-LEVEL CODING CATEGORIES}

Scene-level variables were composed of environmental variables and sociocultural variables. The environmental variables included climate, pollution, scene locales, modes of transportation, and presence of birds and animals.

Type of climate category included absence or presence of depictions of and discussions about the climate as being hot and sunny. Pollution was defined as the absence or presence of depictions of and/or discussions about dirty streets, unclean waters, spoiled food, noisy locales, or overcrowded places. Scene locales were inferred based on visual depictions. Stereotypical locales were defined based on prior research (Mitra, 1999) as places such as natural environments/jungles, huts, temples, caves, palaces, bazaars, and trains/railway stations. Non-stereotypical places included all other locales such as office, street, houses, apartments, shops, hotel/restaurants, barracks/garrison, prison, courts, and schools. Similarly, scenes were coded for the absence or presence of depictions of and/or discussions about stereotypical modes of transportation such as hand-rickshaws, palanquins, animal 
carts, and steam engine trains, whereas the presence of all other modes of transportation such as cars, buses, and motor vehicles were coded as nonstereotypical. Scenes were also coded for absence or presence of depictions of and/or discussions about birds and animals.

Socio-cultural variables at the scene level included religion, leisure activities, status of women, and poverty. In terms of religious practices, scenes were observed for the absence or presence of depictions of and/or discussions about religious practices including magic, witchcraft, and nature worship. Leisure activities were coded as the presence or absence of discussions about and/or depictions of art, crafts, and sports. Stereotypical leisure activities included rope-walking, scorpion-eating, sword-swallowing, fortunetelling, snake-charming, henna painting, pot painting, playing sports such as tiger-hunting, polo, and cricket, and depictions of traditional architecture such as minarets and Hindu temples. Status of women and children was determined by the absence or presence of depictions and/or discussions about sati, arranged marriage, child marriage, dowry, slavery, child sacrifice, child labor, harassment, and rape within the scene. Poverty was defined as the absence or presence of depictions of and/or discussions about beggars, famine-stricken people, homeless, tramps, slaves, servants, manual laborers, subsistence farmers, petty vendors, and fisher folk.

\section{CHARACTER-LEVEL CODING CATEGORIES}

Characters were coded for role, gender, race, occupation, class, place of residence, and language. Based on prior research (Mitra, 1999), stereotypical occupations were defined as unemployed, homemakers, hunters/gatherers, farmers, skilled and unskilled laborers (servant, cleaner, fanner, waterbearer, servers, cart-driver, petty vendors, tourist guides, tailor and secretary, mahout, snake-charmer), thief/gangster, magician, priest, and prostitute/ pimp. Non-stereotypical occupations were defined as managers, professionals (such as lawyers and doctors), land-owners, businesspersons, academicians, tourists, military/police personnel, judges, nurses, entertainers/ artists, politicians, missionaries, and students. The class of the characters was categorized as rich, middle class, or poor based on the character's attire and place of residence. Characters were also coded for whether or not they lived in stereotypical places such as in jungles, on the streets, in huts, temporary dwellings, palaces, temples, and caves.

As part of the analysis, the researcher made additional notes of any relevant images and dialogues that appeared in the films that would further enrich the descriptive account of the portrayals.

\section{Coding Reliability}

To establish reliability, I and another person familiar with Indian culture coded the data. The Potter and Levine-Donnerstein's (1999) modification 
of Scott's pi (Scott, 1955) was used as the basis of calculating inter-coder reliability. Overall scene reliability was $91 \%$ (including country type $=98 \%$, climate $=88 \%$, pollution $=93 \%$; scene locale $=82 \%$ ). Overall character reliability was $86 \%$ (for instance, gender $=100 \%$; ethnicity $=100 \%$; occupation $=80 \%$; language $=84 \%$ ).

\section{RESULTS}

Scene-level Analysis

The first research question addressed in this study revolved around a scenelevel comparison of scenes located in India and in the West. The results related to this research question are presented in the following paragraphs (see Table 1). Qualitative exemplars are provided to enrich the findings.

\section{TYPE OF CLIMATE}

Overall climatic conditions portrayed as extreme and uncontrollable were more likely to be in India $(n=87)$ than in the West $(n=2) ; \chi^{2}=59.1$, $p<.001$. The sun was often talked of in terms of a foe capable of bringing great harm and therefore something that Westerners in particular should protect themselves against. For example in Wee Willie Winkie, a British general instructs his soldiers that in India "the sun can kill a man just as surely, just as swift as a naked bullet."

\section{POLLUTION}

Pollution was associated much more with India $(n=94)$ as compared to the West $(n=7) ; \chi^{2}=542.3 ; p<.001$. It was common to find portrayals of dirty roads, dusty streets, unclean waters, overflowing sewers, marshy streets, and spoilt foods apart from the presence of garbage, depictions of noisy locales or overcrowded places (especially bazaars, trains and stations) in scenes depicting India. Apart from such visual depicters of pollution, there were also several characters that made verbal references to pollution. For example in Wee Willie Winkie, a British sergeant reprimands a British boy thus: "How many times have I told you that in India everything has to be sterilizedthe food you eat, the water you drink?" and at another time, a young American girl is told: "Don't eat any fresh fruit, don't drink any water from the spoils, don't ever go out of the Army gates. Keep out of the sun."

\section{SCENE LOCALES}

Traditional stereotypical locales were much more likely to be set in India $(n=256)$ rather than in the West $(n=30) ; \chi^{2}=148.3 ; p<.001$. The bazaar forms a unique and fascinating location for Western film-makers as an "urban jungle" that is crowded not with trees and undergrowth but people, shops, 
TABLE 1 Scene-Level Analysis of Depictions of India and the West.

\begin{tabular}{|c|c|c|c|c|c|}
\hline Categories & Brief description & $\begin{array}{l}\text { India } \\
(\%, n)\end{array}$ & $\begin{array}{l}\text { West } \\
(\%, n)\end{array}$ & $\chi^{2}$ & $p$ \\
\hline Climate & Hot and sunny & $14.5 \%, 87$ & $0.5 \%, 2$ & 59.1 & $p<0.001$ \\
\hline Pollution & $\begin{array}{l}\text { Dirty/dusty streets, } \\
\text { unclean waters, } \\
\text { spoilt food, } \\
\text { noisy locales } \\
\text { or overcrowded } \\
\text { places }\end{array}$ & $15.5 \%, 94$ & $1.7 \%, 7$ & 52.3 & $p<0.001$ \\
\hline \multirow[t]{2}{*}{$\begin{array}{l}\text { Scene } \\
\quad \text { locales }\end{array}$} & $\begin{array}{l}\text { Stereotypical locales } \\
\text { included jungles, } \\
\text { huts, temples, } \\
\text { caves, palaces, bazaars, } \\
\text { and railway stations }\end{array}$ & $43.3 \%, 256$ & $7.3 \%, 30$ & 148.3 & $p<.001$ \\
\hline & Rural areas & $58.1 \%, 351$ & $16.5 \%, 68$ & 174.3 & $p<.001$ \\
\hline $\begin{array}{l}\text { Modes of } \\
\quad \text { transportation }\end{array}$ & $\begin{array}{l}\text { Stereotypical modes of } \\
\text { transportation included } \\
\text { handrickshaws, } \\
\text { palanquins, animal carts, } \\
\text { and steam engine trains }\end{array}$ & $12.9 \%, 78$ & $1.5 \%, 6$ & 42.2 & $p<.001$ \\
\hline $\begin{array}{l}\text { Birds and } \\
\text { animals }\end{array}$ & $\begin{array}{l}\text { Depictions of birds and } \\
\text { animals in jungles, as } \\
\text { urban beasts of } \\
\text { draught, as modes } \\
\text { of transportation } \\
\text { or as part of discussions } \\
\text { about hunting, sport, } \\
\text { food or diet. }\end{array}$ & $19.2 \%, 116$ & $2.9 \%, 12$ & 58.7 & $p<.001$ \\
\hline $\begin{array}{l}\text { Religious } \\
\text { practices }\end{array}$ & $\begin{array}{l}\text { Stereotypical religious } \\
\text { practices included magic, } \\
\text { witchcraft, and nature } \\
\text { worship }\end{array}$ & $21.7 \%, 131$ & $4.4 \%, 18$ & 58.4 & $p<.001$ \\
\hline $\begin{array}{l}\text { Leisure } \\
\quad \text { activities }\end{array}$ & $\begin{array}{l}\text { Rope-walking, } \\
\text { scorpion-eating, } \\
\text { sword-swallowing, } \\
\text { fortune-telling, } \\
\text { snake-charming, } \\
\text { henna painting, } \\
\text { pot painting, } \\
\text { tiger hunting, polo, } \\
\text { cricket, minarets and } \\
\text { temple architecture }\end{array}$ & $13.2 \%, 80$ & $3.2 \%, 13$ & 29.8 & $p<.001$ \\
\hline $\begin{array}{l}\text { Status of women } \\
\text { and children }\end{array}$ & $\begin{array}{l}\text { Sati, arranged marriage, } \\
\text { child marriage, dowry, } \\
\text { slavery, child sacrifice, } \\
\text { child labor, harassment, } \\
\text { and rape }\end{array}$ & $9.4 \%, 57$ & $1.0 \%, 4$ & 30.9 & $p<.001$ \\
\hline Poverty & $\begin{array}{l}\text { Beggars, famine-stricken } \\
\text { people, homeless, tramps, } \\
\text { slaves, servants, manual } \\
\text { laborers, subsistence } \\
\text { farmers, petty vendors, } \\
\text { and fisher folk }\end{array}$ & $7.9 \%, 48$ & $1.2 \%, 5$ & 22.3 & $p<.001$ \\
\hline
\end{tabular}


and animals. The bazaar also becomes a place where "spectacles" and "mysteries" such as sword-eating, rope-walking, snake-charming, fire-walking, and the like take place.

Rural areas were much more likely to be depicted in scenes in India $(n=351)$ rather than in the West $(n=68) ; \chi^{2}=174.3 ; p<.001$. Also, towns/ villages in India were much more likely than Western locations to remain unidentified and unnamed. When they were named, Indian places were more likely to be given fictitious names, mostly using "-pur/pore" as a suffix. For instance, Ranchipur is the setting for The Rains Came; Tantrapur is where Gunga Din supposedly take place, while Rajpore is one other such non-existent town created for the films. Amongst the real urban locales, Calcutta in India and London in the West were the most frequently occurring featured cities.

\section{MODES OF TRANSPORTATION}

Traditional modes of transportation were much more likely to be presented in scenes portraying India $(n=78)$ than scenes depicting the West $(n=6)$; $\chi^{2}=42.2 ; p<.001$. Not surprisingly, in Rains Came, an English Lord comments to an Indian king as follows: "When I first visited India, I was amazed to find that you people had so many of the modern conveniences... these are the blessing of civilization."

\section{BIRDS AND ANIMALS}

A greater proportion of scenes that were devoted to featuring birds and animals were set in India $(n=116)$ as compared to Western countries $(n=12)$; $\chi^{2}=58.7 ; p<0.001$. Images of actual animals often appear as part of the natural jungle, as urban beasts of draught, and as modes of transportation. Verbal discussions of birds and animals often revolved around hunting, sport, food, and diet. Animals commonly sighted in films about India were elephants, snakes (especially cobras and pythons), tigers, horses, scorpions, panthers, cheetahs, buffalos, cows, monkeys, camels, rats, pigs, bears, lizards, turtles, owls, monitor lizards, jackals, vultures, vampire bats, insects (mosquitoes, beetles and other bugs), and alligators. For example, a young lady (Shirley Temple) visiting India for the first time in the film Wee Willie Winkie has several questions about the fauna in India. She asks her friend, "How do you keep mosquitoes from biting your knees?" and "Have you driven a buffalo before?"

\section{RELIGIOUS PRACTICES}

Religious rituals, superstitious beliefs, magic, and sorcery were more likely to be presented in Indian settings ( $n=131)$ as compared to scenes in the West ( $n=18) ; \chi^{2}=58.4 ; p<.001$. The central theme of films such as Gunga Din, 
Indiana Jones and the Temple of Doom, and The Deceivers revolves around a murderous Indian religious cult called "thuggee". Thuggee are shown as worshippers of Kali, the Hindu Goddess associated with destruction and sorcery, who would kill to please her. In Gunga Din, the thuggee religious sect in introduced as "the most fiendish band of killers that ever existed" and a religious order honoring "Kali-the Goddess of blood." Symbols related to black magic such as blood, skeletons, voodoo dolls and fire were used to portray Kali as an evil, terrible, powerful force who casts a spell on her followers.

Other Indian religious practices depicted were sati, idol worship, cow worship, snake worship, tree worship, and river worship. Magical spells, sorcery, and witchcraft were depicted using symbols such as bloods, voodoo dolls, skulls, and skeletons. Fire worship was typically depicted by the use of fire-torches, lamps, fire cauldrons, and burning grounds for worship. Religion-related persons and gods tht were depicted were Kali, Krishna, Shiva, Buddha, holy saints in saffron robes-topknot-beard meditating under trees and priests in temples. Images of Hindu weddings, dancing with incense/ fire, doing "namaskar" gesture as prayer, golden temples, and statues and chanting of Sanskrit Hindu hymns were depicted in such scenes. Superstition regarding months of the year and the auspiciousness of seeing certain animals figured in some of the films.

\section{LEISURE ACTIVITIES}

There was significantly greater number of scenes of stereotypical leisure activities depicted in India $(n=80)$ than in the West $(n=13) ; \chi^{2}=29.8$; $p<.001$. In Chutney Popcorn, for instance, henna-painting is repeatedly used as a visual reminder of the Indian ethnicity of the lead role character. In films like The Man Who Would be King, The Jungle Book, The River, and Wee Willie Winkie, a series of images of fortune-telling, scorpion-eating, sword-juggling and the like are used to define an Indian bazaar.

\section{STATUS OF WOMEN AND CHILDREN}

The number of scenes in which women and children were portrayed as victims of abuse was much greater in scenes set in India $(n=57)$ that those set in the West $(n=4) ; \chi^{2}=30.9 ; p<.001$. Women and children in India were often shown as being victims of a socio-religious-cultural system. For example, in The Autobiography of a Princess portrays the following discussion:

Princess: "Ours wasn't a backward state. Not compared to others."

Cyril Saab: "There were worse."

Princess: "Much worse. When you think of Tadpur, child sacrifices, so many cases of Sati, we hardly had any Sati at all." 
Similarly in The River, the protagonist explains the arranged marriage of an Indian girl: "Then her father told her that she must marry a man of his choice ... that's the ancient custom." In this film, Harriet, an English girl, talks about how Indian parents are disappointed when they have a girl baby because they need to get a dowry. In City of Joy, the main Indian character, Hazari, says several times how important a duty it is for a father to save money of his daughter's dowry. Similarly, in Around the World in Eighty Days, the British lead character Phileas Fogg saves an Indian princess from sati just like Indiana Jones in the film, Indiana Jones and the Temple of Doom saves starved children from bonded labor in the clutches of an evil cult.

\section{POVERTY}

Among scenes that portrayed poverty in these films, a significantly greater proportion was likely to be in Indian scenes $(n=48)$ rather than in the Western scenes $(n=5) ; \chi^{2}=22.3 ; p<.001$. Scenes with poor people were usually depicted as a backdrop as part of the crowd in Indian streets and as helpers in British colonial quarters in India. However, in films such as City of Joy, Indiana Jones and the Temple of Doom, and Black Narcissus, poverty forms an important part of the plot itself. In such films, the Western characters (often missionaries) are portrayed as "good Samaritans" who save the poor and wretched in India. Apart from actual depictions of poverty, there were also many discussions amongst characters about poverty. For instance, in Foreign Body, there are references made to poverty by using phrases such as "thousands sleeping in the street" and "the black hole of Calcutta."

\section{Character-level Analysis}

The second research question focused on the character level assessment of any significant differences in portrayals of Indian versus non-Indian characters in the movies that were examined in this study. The results of these analyses are presented below (see Table 2).

\section{ROLE}

The lead roles in the coded films were slightly more likely to be played by non-Indian characters $(n=18)$ as compared to non-Indian characters $(n=39) ; \chi^{2}=6.7 ; p<0.01$.

\section{GENDER}

There were more male characters than female ones in the films included in this sample. However, the gender divide was much more pronounced amongst Indian characters as compared to non-Indian characters with slightly more male characters that were Indian $(n=150)$ as compared to Western $(n=137) ; \chi^{2}=7.7 ; p<0.01$. 
TABLE 2 Character-Level Analysis of Depictions of Indian and Non-Indian Characters.

\begin{tabular}{|c|c|c|c|c|c|}
\hline Categories & Brief description & India $(\%, n)$ & West $(\%, n)$ & $\chi^{2}$ & $p$ \\
\hline Role & Characters in lead role & $9.0 \%, 18$ & $17.6 \%, 39$ & 6.7 & $p<0.01$ \\
\hline Gender & Characters who are male & $75.0 \%, 150$ & $62.0 \%, 137$ & 7.7 & $p<0.01$ \\
\hline Occupation & $\begin{array}{l}\text { Characters depicted in } \\
\text { stereotypical occupations } \\
\text { such as hunters, farmers, } \\
\text { thieves, magicians, priests, } \\
\text { prostitutes, homemakers, } \\
\text { unemployed people and } \\
\text { laborers (such as servants, } \\
\text { cleaners, fanners, } \\
\text { water-bearers, petty vendors, } \\
\text { tourist guides, mahouts, } \\
\text { and snake-charmers) }\end{array}$ & $66.0 \%, 126$ & $37.6 \%, 74$ & 31.3 & $p<0.001$ \\
\hline Class & $\begin{array}{l}\text { Characters depicted as poor as } \\
\text { inferred from their attire } \\
\text { and place of residence }\end{array}$ & $44.7 \%, 88$ & $9.2 \%, 20$ & 67.9 & $p<.001$ \\
\hline $\begin{array}{l}\text { Place of } \\
\text { residence }\end{array}$ & $\begin{array}{l}\text { Characters depicted as living } \\
\text { in stereotypical places such } \\
\text { as in jungles, on the streets, } \\
\text { in huts, temporary dwellings, } \\
\text { palaces, temples, and caves }\end{array}$ & $65.7 \%, 88$ & $12.0 \%, 16$ & 80.7 & $p<0.001$ \\
\hline Language & $\begin{array}{l}\text { Characters depicted as speaking } \\
\text { Indian languages and } \\
\text { broken English }\end{array}$ & $83.5 \%, 167$ & $1.8 \%, 4$ & 290.4 & $p<0.001$ \\
\hline
\end{tabular}

\section{OCCUPATION}

The findings suggest that stereotypical occupations were much more likely to be taken on by Indian characters $(n=126)$ as compared to non-Indians $(n=74) ; \chi^{2}=31.3 ; p<.0001$. In talking about the state of employment, the main character Ram Das in Foreign Body comments that "Calcutta was bulging at the seems with unemployed men". Several films show Indian servants sweeping the floors, working in the garden, tending to horses, carrying luggage on the head, bowing and saluting, serving food, and doing manual labor in the sun as a back-drop to the main narrative.

\section{CLASS}

Characters depicted as poor were much more likely to be Indian $(n=88)$ rather than non-Indian characters $(n=20) ; \chi^{2}=67.9 ; p<.001$. Poor people were defined as those who wore rags, tatters, worked as laborers, beggars, slaves and vendors, and lived in huts, temporary shelters or in the wild. On the other hand, upperclass people were those who wore expensive clothes in silk, jewelry, lived in palatial homes (e.g., palaces and mansions), and could afford several luxuries like big feasts, servants, and so on, and, middle-class persons were those who could afford casual clothes are those 
that are in good shape (not tattered), live in houses or apartments, and have a reasonable but not luxurious lifestyle.

\section{PLACE OF RESIDENCE}

Characters' features are residing in stereotypical places were much more likely to be Indian characters $(n=88)$ than non-Indian characters $(n=16) ; \chi^{2}=80.7 ; p<.001$. Stereotypical places were defined as the wild (especially jungles), on the streets (homeless), huts, temporary dwellings, palaces, temples, caves, and dens. On the other hand, both Indian and non-Indian characters were almost equally likely to reside in non-stereotypical places such as houses, apartments, mansions, schools, and garrisons. In City of Joy, for example, the central character, Hazari, and his family are shown living in the streets, slums and in dilapidated huts while Mowgli from The Jungle Book spends almost his entire life living in the wild jungles of North India.

\section{LANGUAGE}

Characters speaking Indian languages (such as Hindi) and in accented Indian English were much more likely to be Indian $(n=167)$ than non-Indian characters $(n=4) ; \chi^{2}=290.4 ; p<.001$. Western characters on the other hand, spoke Western English and hardly any Indian languages. Sometimes Indian characters actually spoke in gibberish nonsensical language that was meant to represent an Indian language. Indian characters were also more likely to be showing talking in broken English and heavily accented English. For example, in Stiff Upper Lips, the British Uncle not only imitates the Indian accent but also says that non-verbal signs like "wobbling the head from side to side" are a part and parcel of Indian English. Similarly, in The Party, the Indian character called Bakshi talks in an exaggerated heavily accented Indian English with peculiar choice of words and grammer (e.g., "I want to be going to...", "I am not understanding you"). In the Foreign Body, an Englishman says to the Indian character: "I guessed you were Indian when you telephoned. I could always tell by your voice."

\section{DISCUSSION}

In summarizing the results, in appears that depictions of hot, polluted, mostly rural in nature locales (e.g., bazaars, palaces, huts, jungles, caves, and temples filled with animals) and traditional modes of transport (such as handrickshaws and elephant rides) are much more often represented in scenes located in India rather than in the West. Depictions of religious practices (such as nature worship and sorcery), abuse of women and children (such as sati and dowry), and people engaged in stereotypical leisure activities (such as snake-charming, fire-walking, rope-walking) were also more likely 
to be featured in Indian settings rather than non-Indian settings in these feature films. Characters portrayed as poor, having traditional occupations (such as hunters, magicians, and dance girls), living in stereotypical places (such as huts and jungles), and speaking exaggerated accented English were more likely to be Indian as compared to non-Indian. In short, the above findings suggest that a definitive pattern of stereotypical portrayals of India appears in films made in the West.

Overall, the imagery of India seems to be created to make clear-cut distinctions to emphatically categorize it as an out-group. Such biased portrayals are not limited to specific movies but repeat themselves across narrative. Therefore, these stereotypical portrayals are not reflections of the idiosyncratic preferences of individual creators of media content but seem to be a part of the larger societal meanings and myths existing in the West about "Indian-ness." Existence of such shared cultural stereotypes as opposed to individual stereotypical beliefs makes it easier for people in power to discriminate against out-groups in ways that are legitimized by social institutions and eventually leading to institutional prejudice. Therefore mediated cultural stereotypes may shape the collective consciousness of negative prejudicial attitudes of Western audiences towards India as a whole.

Also, it is possible that negative stereotypes in media serve as a means of downward social comparisons in order to boost the self-image of Western audiences. Such comparisons have implications for social justifications that could be provided for cultural imperialism of the West by establishing Indian peoples as inferior and incompetent who need to be civilized. It also suggests the kinds of prejudicial feelings of paternalism and pity that could be seen as appropriate toward inept subordinates. Further research needs to explore the relationships between cultural stereotypical traits and emotional feelings toward out-groups.

At the individual-viewer level, social cognitive media effects perspectives inform us that such stereotypical portrayals may lead to formation of "schemas" for India as well as make vivid mediated exemplars easily accessible while making social judgments. These perceptions and evaluations in turn are likely to impact the ways we act towards with these people in real-life encounters. Thus, in a global space, while interacting with the flesh-and-blood persons from around the world, we may also be responding at a less conscious level to the cultural memories that we already have of these groups of people. Therefore, given that mediated experiences often color one's perceptions and feelings about a stereotyped group, an increased awareness and critical media viewing skills may be useful. Future experimental research needs to be conducted to examine how exposure to stereotypical media content might influence perceptions and feelings of U.S. audiences towards people living in third world countries such as India.

Not only will the types of stereotypes found in the media have implications of Western audience but also for members of the stigmatized groups in 
terms of self-stereotyping effects of exposure to such portrayals. With the increased availability of Western media products in third world countries, it is likely that even viewers belonging to the stereotyped group might reconceptualize their own identities based on their encounters with media portrayals of their group in the dominant culture. In other words, stereotypical depictions in mainstream media might dictate what are expected and acceptable behaviors by members of target groups, especially in terms of interpersonal interactions with members of other groups (Armstrong et al., 1992; Ford, 1997; Mastro \& Tropp, 2004). Such imagined identities then influence what is the acceptable social norm for behaviors, dress, and other cultural symbols for the minority group. Adherence by minority group members to these stereotypical roles further strengthens the notion that the stereotypes are accurate.

Perhaps one effective way for people who belong to the marginalized stereotyped groups to reclaim and reconstruct their own histories is to directly participate in media production by making their voices heard in the process of creations of media narratives about their group. That is, racial and ethnic diversity in the media workplace may be crucial to inclusion of less stereotypical and more varied portrayals of minority groups. However, the mere presence of people from diverse nations and racial backgrounds in a workplace in itself may not be as effective as allowing such individuals to express themselves freely and participate in dialogical conversations such that their inputs are listened to respectfully.

Further research needs to trace how stereotypes about India have changed with time and whether these changes can be attributed to socio-politicaleconomic inter-dependencies among first and third world countries. Although a similar analysis was attempted in the current study, the small sample size of 25 films restricted the scope of such analyses to provide any meaningful conclusions. Such an examination would help understand if stereotypes are resistant to change, making them rather stable across time.

In terms of methodological implications, the findings of the current study help us understand that stereotypes should be treated as multi-dimensional concepts. Traditionally, stereotypes have been defined narrowly in terms of personality traits associated with members of a group. In contrast, a broader conceptualization of stereotypes has been used for this study, encompassing not just personality traits but also socio-cultural characteristics such as poverty, calamities, and so on. In addition, cultural stereotypes of Indians revealed in the current study encompass several negative as well as seemingly positive beliefs. For instance, Indians were seen as having many riches. However, past research studies have shown that even positive stereotypes (e.g., "model minorities" for Asian Americans) could lead to stereotypical attitudes and even discrimination because they do not acknowledge the differences amongst a group of people and lead to unrealistic associations of certain traits with certain groups of people (Lee, 1996; Wu, 2002). 
Future researchers would also benefit from taking into consideration some of the limitations of this study. For instance, while the current study only included films produced in the United Kingdom, and the United States, scholars interested in further research in this area could also consider other European countries that colonized India (such as Netherlands and Portugal) and countries whose scholars have actively translated many Indian texts (such as Germany and France). In addition, stereotypes and marginalization of the third world could also be studied in other media contexts such as literature (fictional novels, children's literature, textbooks), print media (news stories, cartoons, magazines), and new media such as the Internet. While content analyses like the present one cannot determine cause-andeffect relationships between media exposure to people from the Third World and behavioral outcomes such as hate crimes and institutional prejudice, such research serves as the first step toward untangling these complex inter-related yet socially relevant links apart from motivating media creators in the West to consider alternative, complex, less stereotypical representations for peoples of other cultures.

\section{NOTES}

1. There has been a long history of the use of terms such as developing countries, Third World nations etc. I use the term Third World and First World merely to refer to the differences between these two worlds but do not mean to suggest the superiority of one over the other. The First World and the West are used interchangeably in this paper. These terms are used to denote European-North American countries.

2. Originally 30 films were selected randomly using random number generator software. Six of them were excluded from the study since they did not fit the study profile either because they did not feature Indians (for example, they featured American Indians) or did not feature India (for example, they featured islands in the Bay of Bengal but not in India) or were not full-length feature films (for example, they were mini-series for television audiences).

3. At the time of data collection for this project, only movies released until the year 2000 were available on VHS or DVD format. Hence the end data was decided as 2000.

4. The West was defined as the United States, the United Kingdom, Canada, Europe, Australia, and New Zealand.

\section{REFERENCES}

Armstrong, G. B., Neuendorf, K. A., \& Brentar, J. E. (1992). TV entertainment, news, and racial perceptions of college students. Journal of Communication, 42, $153-176$.

Brown, J. \& Campbell, K. (1986). Race and gender in music videos: The same beat but a different drummer. Journal of Communication, 36(1), 94-106.

Busselle, R. W. \& Crandall, H. (2002). Television viewing and perceptions about race differences in socioeconomic success. Journal of Broadcasting E Electronic Media, 46, 265-282.

Busselle, R. W. \& Shrum, L. J. (2003). Media exposure and exemplar accessibility. Media Psychology, 5, 255-282. 
Cameron, K. M. (1990). Paul Robeson, Eddie Murphy, and the film text of "Africa". Text \& Performance Quarterly, 10, 282-293.

Coltrane, S. \& Messineo, M. (2000). The perpetuation of subtle prejudice: Race and gender imagery in 1990s television advertising. Sex Roles, 42, 363-389.

Crocker, J. \& Major, B. (1989). Social stigma and self-esteem: The self-protective properties of stigma. Psychological Review, 96, 608-630.

Cyr, H. W. (1991). The Third World in film and video, 1984-1990. Metuchen, NJ: Scarecrow Press.

Entman, R. M. (1992). Blacks in the news: Television, modern racism and cultural change. Journalism Quarterly, 69, 341-361.

Entman, R. M. (1994a). African Americans according to TV news. Media Studies Journal, 8, 29-38.

Entman, R. M. (1994b). Representation and reality in the portrayal of Blacks on network television news. Journalism Quarterly, 71, 509-520.

Fein, S. \& Spencer, S. J. (1997). Prejudice as self-image maintenance: Affirming the self through derogating others. Journal of Personality and Social Psychology, 73(1), 31-44.

Festinger, L. (1954). A theory of social comparison processes. Human Relations, 7, $117-140$.

Fiske, S. T. \& Taylor, S. E. (1991). Social cognition (2nd ed.). New York: McGrawHill.

Ford, T. E. (1997). Effects of stereotypical television portrayals of African-Americans on person perception. Social Psychology Quarterly, 60, 266-275.

Fujioka, Y. (1999). Television portrayals and African American stereotypes: Examination of television effects when direct contact is lacking. Journalism \& Mass Communication Quarterly, 76, 52-75.

Gallagher, M. (1989). A feminist paradigm for communication research. In B. Dervin, L. Grossberg, B. J. O'Keefe, \& E. Wartella (Eds.), Rethinking communication: Paradigm exemplars (Vol. 1, 75-87). Newbury Park, CA: Sage.

Gerbner, G. (1998). Cultivation analysis: An overview. Mass Communication \& Society, 1, 175-194.

Gerbner, G., Gross, L., Morgan, M., Signorielli, N., \& Shanahan, J. (2002). Growing up with television: Cultivation processes. In J. Bryant \& D. Zillmann (Eds.), Media effects: Advances in theory and research (2nd ed., pp. 43-67). Mahwah, NJ: Lawrence Erlbaum.

Gibson, R. \& Zillmann, D. (2000). Reading between the photographs: The influence of incidental pictorial information on issue perception. Journalism \& Mass Communication Quarterly, 77, 355-366.

Hansen, C. H. \& Krygowski, W. (1994). Arousal-augmented priming effects: Rock music videos and sex object schemas. Communication Research, 21(1), 24-47.

Kaplan, A. E. (1997). Looking for the other: Feminism, film, and the imperial gaze. New York: Routledge.

Lee, S. J. (1996). Unraveling the "model minority" stereotype: Listening to Asian American youth. New York: Teachers College Press.

Macrae, C. N., Bodenhausen, G. V., Milne, A. B., Castelli, L., Schloerscheidt, A. M., \& Greco, S. (1998). On activating exemplars. Journal of Experimental Social Psychology, 34, 330-354. 
Mastro, D. E. \& Greenberg, B. S. (2000). The portrayal of racial minorities on prime time television. Journal of Broadcasting \& Electronic Media, 44, 690-703.

Mastro, D. E. \& Stern, S. R. (2003). Representations of race in television commercials: A content analysis of prime-time television. Journal of Broadcasting $\mathcal{E}$ Electronic Media, 47, 638-642.

Mastro, D. E. \& Tropp, L. R. (2004). The effects of interracial contact, attitudes, and stereotypical portrayals on evaluations of Black television sitcom characters. Communication Research Reports, 21, 119-130.

Matabane, P. W. (1988). Television and the Black audience: Cultivating moderate perspectives on racial integration. Journal of Communication, 38, 21.

Merchant, U. (1998). Picturing ourselves: South Asian identities within the image. Cultural studies from Birmingham, 2(1). Retrieved October 10, 2005, from http://artsweb.bham.ac.uk/bccsr/issue1/merchant.htm

Mitra, A. (1999). India through the Western lens: Creating national images in film. Thousand Oaks, CA: Sage Publications.

Mok, T. (1998). Getting the message: Media images and stereotypes and their effect on Asian Americans. Cultural Diversity and Mental Health, 4, 185-202.

Mowlana, H. \& Wilson, L. (1990). The passing of modernity: Communication and the transformation of society. New York: Longman.

Narayan, U. (1997). Dis-locating cultures: Identities, traditions, and third-world feminism. New York: Routledge.

Oliver, M. B. (1994). Portrayals of crime, race, and aggression in reality-based police shows: A content-analysis. Journal of Broadcasting \& Electronic Media, 38, $179-192$.

Oliver, M. B. \& Kalyanaraman, S. (2002). Appropriate for all viewing audiences? An examination of violent and sexual portrayals in movie previews featured on video rentals. Journal of Broadcasting \& Electronic Media, 46, 283-299.

Peterson, R. C., Thurstone, L. L., Shuttlesworth, F. K., \& May, M. A. (1933). Motion pictures and the social attitudes of children. New York: The Macmillan company.

Scott, W. (1955). Reliability of content analysis: The case of nominal scale coding. Public Opinion Quarterly, 17, 321-325.

Shapiro, M. A. \& Lang, A. (1991). Making television reality: Unconscious processes in the construction of social reality. Communication Research, 18, 685-705.

Shohat, E. (1991). Gender and culture of empire: Toward a feminist ethnography of the cinema. Quarterly Review of Film \& Video, 13(1-2), 45-84.

Shohat, E. \& Stam, R. (1994). Unthinking Eurocentrism: Multiculturalism and the media. New York: Routledge.

Shome, R. (1996). Race and popular cinema. The rhetorical strategies of whiteness in city of joy. Communication Quarterly, 44, 502-518.

Tajfel, H. \& Turner, J. C. (1979). An integrative theory of intergroup conflict. In W. Austin \& S. Worchel (Eds.), Social cognition: Perspectives on everyday understanding (pp. 113-140). New York: Academic Press.

Taylor, C. R. \& Lee, J. Y. (1994). Not in vogue: Portrayals of Asian Americans in magazine advertising. Journal of Public Policy \& Marketing, 23, 239-245.

Taylor, S. E. \& Crocker, J. (1981). Schematic bases of social information processing. In E. T. Higgins, P. Herman, \& M. P. Zanna (Eds.), Social cognition: The Ontario symposium (Vol. 1, pp. 89-134). Hillsdale, NJ: Erlbaum. 
Thomas, M. E. \& Treiber, L. A. (2000). Race, gender, and status: A content analysis of print advertisements in four popular magazines. Sociological Spectrum, 20, $357-371$.

Ukadike, F. N. (1990). Western film images of Africa: Genealogy of an ideological formulation. The Black Scholar, 21, 30-48.

Wicks, R. H. (1992). Schema theory and measurement in mass communication research: Theoretical and methodological issues in news information processing. In S. A. Deetz (Ed.), Communication Yearbook (Vol. 15, pp. 115-145). Newbury Park, CA: Sage.

Wills, T. A. (1987). Downward comparison as a coping mechanism. In C. R. Snyder \& C. E. Ford (Eds.), Coping with negative life events: Clinical and social psychological perspectives (pp. 243-268). New York: Plenum Press.

Wu, F. H. (2002). Yellow: Race in America beyond Black and White. New York: Basic Books.

Zillmann, D. \& Brosius, H. B. (2000). Exemplification in communication: The influence of case reports on the perception of issues. Mahwah, NJ: Lawrence Erlbaum. 


\title{
APPENDIX: LIST OF FILMS RANDOMLY CHOSEN FOR ANALYSIS (IN ALPHABETICAL ORDER)
}

\author{
Around the World in Eighty Days \\ Autobiography of a Princess \\ Black Narcissus \\ Bonnie Scotland \\ Chutney Popcorn \\ City of Joy \\ Deceivers, The \\ Foreign Body \\ Gunga Din \\ Indiana Jones and the Temple of Doom \\ Jungle Book, The \\ Little Princess, The \\ Man Who Would be King \\ Millionairess, The \\ Mississippi Masala \\ Party, The \\ Rains Came, The \\ River, The \\ Sammy and Rosie Get Laid \\ Sea Wolves \\ Shadows on the Stairs \\ Stiff Upper Lips \\ Wee Willie Winkie \\ When Knights Were Bold
}

